\title{
Does Factor Accumulation or Productivity Change Drive Output Growth in the Indian Sugar Industry? An Inter-state Analysis
}

\author{
Nitin Arora' ${ }^{1}$ \& Sunil Kumar $2,3,4$
}

ABSTRACT

\begin{abstract}
The study endeavors to break down output growth in the Indian sugar industry into the 'perspiration' component that corresponds to factor accumulation and the 'inspiration' component that corresponds to the total factor productivity (TFP) growth. The bootstrapped Malmquist productivity index has been used as a technique to obtain the TFP growth from the period 1974/75 to 2004/05. Empirical analysis reveals that output growth in the Indian sugar industry is equally driven by the inspiration component (i.e., TFP growth) and the perspiration component (i.e., factor accumulation), but in opposite directions. The inspiration component is observed to contribute to output growth positively, whereas the perspiration component contributes negatively. Given substantial TFP growth, the potential output growth in the Indian sugar industry has been restricted primarily by the negative growth of inputs during the entire study period and particularly in the post-reform period.
\end{abstract}

KEY WORDS: $\quad$ malmquist productivity index; data envelopment analysis; Indian sugar industry.

JEL Classification: C02, C69, D24

${ }^{1}$ Panjab University, India; ${ }^{2}$ South Asian University, India; ${ }^{3}$ Punjab School of Economics, India; ${ }^{4}$ Guru Nanak Dev University, India

\section{Introduction}

The present study has been undertaken with the primary objective of analyzing the sources of output growth in the Indian sugar industry at both national and regional (i.e., state) levels. The relevance of the study stems from the fact that the development of the sugar industry in India provides high backward and forward linkages to the Indian economy given the following about the sugar industry: i) it is the second largest agriculture-based industry in India after the cotton-textile industry; ii) it provides direct employment to 0.5 million and indirect

Correspondence concerning this article should be addressed to: Nitin Arora, Department of Economics, Top Floor, Arts Block-III, Panjab University, Chandigarh-160014, India. email: nitineconometrics@gmail.com. employment to 55 million skilled and unskilled workers (Sanyal, Bhagria, \& Ray, 2008); iii) it contributes Rs. 25 billion annually to the centre and state exchequer in the form of taxes; iv) it has the potential to generate $5000 \mathrm{MW}$ surplus power through the process of cogeneration; and v) it supports the petroleum blending program through the production of ethanol using molasses, a byproduct of sugar. Despite these facts, the sugar industry in India has been weakened by ineffective policy planning. More than 162 sugar mills in India are considered 'sick', (Thomas, 2010). The number of sick mills is high by all standards, underscoring the abysmal health of the Indian sugar industry. Given the industry's appalling health, there is an urgent need to analyze the growth performance of the industry (see Pandey (2007) and Kumar and Arora (2010) for the detailed state of the Indian sugar industry). 
In his seminal work, Solow (1957) developed a growth accounting framework indicating that the observed output growth can be decomposed into its two mutually exclusive components, the 'perspiration' component corresponding to factor accumulation and the 'inspiration' component corresponding to total factor productivity (TFP) growth. Nonetheless, there is a broad consensus among economists, pundits, and policymakers that only the dominance of the inspiration component (i.e., the presence of positive trends in TFP growth) can lead to sustained output growth because it ensures efficient utilization of key resources. Further, the output growth generated only by increasing inputs will not be sustainable in the long run because the expansion of inputs would experience diminishing returns to scale.

It is significant to note that TFP growth includes technological improvements as well as better utilization of capacities, learning by doing and improved skills of labor. More specifically, TFP growth is a composite measure of technological change and changes in the efficiency with which known technology is applied to production processes (Ahluwalia, 1991). Thus, TFP growth is regarded as the consequence of two rather different factors. The adoption of technical innovations in processes and products, shifting the production frontier upward, is measured by the technical change, while the technical efficiency change reflects the capacity of the firms to improve production with given inputs and available technology.

In India, considerable research has been conducted on the TFP growth of the Indian manufacturing sector. Existing research contains studies in three distinct categories. The first category includes studies that concentrate on measuring TFP growth at highly aggregated levels see, for example (Goldar \& Kumari, 2003; Neogi \& Ghosh, 1998; Pradhan \& Barik, 1999; Singh, 2000-01). The focus of the second category is on the analysis of TFP growth in a single manufacturing industry see, for example (Beri, 1962; Dawar, 1990; Gupta \& Patel, 1976; Mehta, 1974; Sastry, 1966; Sharma \& Upadhayay, 2003-04; Singh \& Singh, 1984; Singh \& Agarwal, 2006). There are relatively few studies in the third category, which analyzes the interstate variations in TFP growth for a single industry or group. See, for example(Chattopadhyay, 2004; Kumar, 2003; Kumar \& Arora, 2009; Mitra, 1999; Ray, 1997;
Ray, 2002; Singh, 1964). Barring a few exceptions, most of the studies on the TFP growth of the Indian manufacturing sector have concentrated on the analysis of trends in technical progress or technical change, with the implicit assumption that productive capacity is fully realized and there is no technical inefficiency in the production process. Therefore, the TFP has been equated with technical progress. However, identifying TFP growth solely in regard to technical progress and ignoring technical efficiency change leads to incorrect inference. In addition, scant attention has been paid in existing studies to breaking down output growth into input growth and TFP growth. Thus, the present study endeavors to mitigate the prevailing void among Indian manufacturing studies and particularly intends to examine the sources of output growth in the Indian sugar industry at both national and regional levels.

To check whether output growth in the Indian sugar industry at regional levels is driven by inspiration or perspiration components (i.e., technology-driven or input-driven), the output growth has been decomposed into input growth and TFP growth. The TFP growth has been further classified into the following components: a) technological change and b) technical efficiency change. To pursue these objectives, the study is outlined as follows: Section 2 offers the methodology applied to obtain and bootstrap the data envelopment analysis (DEA) based on the Malmquist productivity index. Section 3 is empirical in nature and endeavors to decompose output growth in the Indian sugar industry into inspiration and perspiration components. The final section concludes the study and provides relevant policy implications.

\section{Research Design}

The empirical analysis is confined to the period of 31 years from $1974 / 75$ to $2004 / 05$, which has been further divided into two sub-periods on the basis of changes in macroeconomic policy governing the Indian economy: i) Pre-reform period (1974/75 to 199091) and ii) Post-reforms period (1991/92 to 2004/05). The required data have been provided by the 'Annual Survey of Industries (ASI) wing of the Ministry of Statistics and Programme Implementation (MOSPI), Government of India, on the payment basis. The following steps have been followed to achieve the objectives of the present study: 
Table 1. Descriptive Statistics of CDS spreads in the sample

\begin{tabular}{lc}
\hline Variable & Description \\
\hline 1) Output: & Net Output + Depreciation \\
a) Gross Output & Production Workers + Non-Production Workers \\
1) Inputs: & Raw Material + Fuel Consumed \\
a) Labor & Capacity Utilization×(Net Fixed Capital + Depreciation) \\
b) Intermediate Inputs & \\
c) Gross Fixed Capital in Use &
\end{tabular}

\section{Step 1: Construction of Input and Output Variables} The foremost requirement for computing technical efficiency levels in the sugar industry of 12 major sugarproducing states is to specify a set of input and output variables. Our set of variables includes single-output and three-input variables. A detailed description of these variables is given in Table 1.

Notably, the gross fixed capital (GFC) has been adjusted according to the capacity utilization levels to reflect the fact that what belongs in a production function is 'capital in use' and not 'capital in place' (Solow, 1957). Thus, the 'gross fixed capital (GFC) in use' is a more appropriate proxy for capital input. Further, except for the labor input (which is measured by the number of workers), all other inputs as well as the output data are reported in the value terms. All nominal values are deflated by appropriate wholesale price indices to obtain real values. Gross output has been deflated by the price index for sugar and sugar products; investment has been deflated using the implicit deflator for gross fixed capital formation for registered manufacturing; expenditure on fuels has been deflated using the price index for fuel power and lubricants; and material expenditures have been deflated using the general wholesale price index for all commodities.

Moreover, with an objective to minimize the presence of heterogeneity in the data set, we followed Kumar (2001), Kumar (2003), and Kumar (2006), Ray (1997), Ray (2002), and constructed the state level input-output quantity data for a 'representative firm' in the industry. For this, the state-level aggregate figures have been divided by the number of firms operating in the state. The advantage of using data for a 'representative firm' is that it imposes fewer restrictions on the production technology. The firm level input-output pairs are fea- sible, although not individually reported. Therefore, by the assumption of convexity, the average input-output bundle will always be feasible. The aggregate inputoutput bundle will be feasible only under the condition of non-additivity of technology (Ray, 2002). In addition, this reduces the effects of random noise due to measurement errors in inputs and output(s).

Step 2: Measuring Total Factor Productivity Growth This research outlines two basic approaches for measuring TFP growth: i) the econometric estimation of a production, or cost, or some other function and ii) the construction of index numbers using non-parametric methods. In this study, we adopted the latter because it does not require the imposition of a possibly unwarranted functional form on the structure of the production technology as required by the econometric approach. Three different indices are frequently used to evaluate TFP growth-the Fisher, Törnqvist, and Malmquist indices. The Malmquist productivity index (MPI) has been selected to analyze the productivity growth in the manufacturing sector of 12 major sugar-producing states in India. This selection was made because only the MPI i) allows the decomposition of productivity changes into two mutually exclusive components, namely, a) technical efficiency change and b) technological change; ii) it does not require price data, thereby avoiding the problems associated with unavailability or distortions of price information; and iii) it does not require a pre-specified optimizing criterion such as cost minimization or profit maximization. The main disadvantage of the MPI is the lack of a stochastic specification, thus making it insensitive to any random shocks or data measurement errors.

The MPI, as proposed by Caves, Christensen and Diewert (1982) is defined using distance functions that 
allow one to describe multi-input, multi-output production technology without involving explicit price data and behavioral assumptions (such as cost minimization or profit maximization). One may define either input- or output-oriented distance functions. An inputoriented distance function characterizes the production technology by looking at a minimal proportional contraction of the input vector given an output vector. An output-oriented distance function considers a maximal proportional expansion of the output vector given an input vector. For purposes of this study, we utilize the output-oriented distance functions to calculate MPI because the sugar manufacturing firms are more likely to try to increase their outputs given their use of inputs, rather than to try to decrease inputs given their outputs.

Before we define the distance function, we first define the technology. Consider a sample of $K$ states using $x^{t} \in R_{+}^{N}$ inputs in the production of $y^{t} \in R_{+}^{M}$ outputs in time period $t, t=1, \ldots, T$. The graph of the production technology in period $t$ is the set of all the feasible input-output vectors

$G R^{t}=\left\{\left(y^{t}, x^{t}\right), x^{t}\right.$ can produce $\left.y^{t}\right\}, t=1, \ldots, T$

Where the technology is assumed to have the standard properties, such as convexity and strong disposability, described in Färe et al. (1994).

A multiple-input, multiple-output production technology can be represented by the production possibility set which is defined in terms of $G R^{t}$ as

$P^{t}\left(x^{t}\right)=\left\{y^{t}:\left(y^{t}, x^{t}\right) \in G R^{t}\right\}, t=1, \ldots, T$

A functional representation of the technology is provided by Shephard's (1979) output-oriented distance function:

$D_{o}^{t}\left(x^{t}, y^{t}\right)=\min _{\theta}\left\{\theta: \frac{y^{t}}{\theta} \in P^{t}\left(x^{t}\right), \theta>0\right\}, \quad t=1, \ldots, T$

The distance function is less than or equal to one if and only if the output $y$ belongs to the output set. The manufacturing sector of the state is considered technically efficient if the distance function equals one and the values less than one indicate the presence of technical inefficiency.

The TFP change, measured by the MPI, between periods $t$ and $t+1$, can be defined using the period $t$ technology as
$M_{o}^{t}\left(x^{t+1}, y^{t+1}, x^{t}, y^{t}\right)=\frac{D_{o}^{t}\left(x^{t+1}, y^{t+1}\right)}{D_{o}^{t}\left(x^{t}, y^{t}\right)}$

Similarly, the MPI using period $t+1$ technology may be defined as:

$M_{o}^{t+1}\left(x^{t+1}, y^{t+1}, x^{t}, y^{t}\right)=\frac{D_{o}^{t+1}\left(x^{t+1}, y^{t+1}\right)}{D_{o}^{t+1}\left(x^{t}, y^{t}\right)}$

To avoid choosing the MPI of an arbitrary period, Färe $e t$ al. (1994) specified the Malmquist productivity change index as the geometric mean of equations (4) and (5):

$M_{o}\left(x^{t+1}, y^{t+1}, x^{t}, y^{t}\right)=\sqrt{\frac{D_{o}^{t}\left(x^{t+1}, y^{t+1}\right)}{D_{o}^{t}\left(x^{t}, y^{t}\right)} \frac{D_{o}^{t+1}\left(x^{t+1}, y^{t+1}\right)}{D_{o}^{t+1}\left(x^{t}, y^{t}\right)}}$

Färe et al. (1994) further state that the MPI formula in equation (6) can be equivalently rewritten as:

$M_{o}\left(x^{t+1}, y^{t+1}, x^{t}, y^{t}\right)=$

$=\frac{D_{o}^{t+1}\left(x^{t+1}, y^{t+1}\right)}{D_{o}^{t}\left(x^{t}, y^{t}\right)} \sqrt{\frac{D_{o}^{t}\left(x^{t+1}, y^{t+1}\right)}{D_{o}^{t+1}\left(x^{t+1}, y^{t+1}\right)} \frac{D_{o}^{t}\left(x^{t}, y^{t}\right)}{D_{o}^{t+1}\left(x^{t}, y^{t}\right)}}$

The first ratio on the right-hand side of equation (7) measures the changes in technical efficiency between period $t$ and $t+1$ as catching up to the frontier effect. The second term measures the change in production technology (i.e., technical change) usually referred to as a shift in production frontier.

Technical Efficiency Change $=E C=\frac{D_{o}^{t+1}\left(x^{t+1}, y^{t+1}\right)}{D_{o}^{t}\left(x^{t}, y^{t}\right)}$

Technological Change $=T C=$

$=\sqrt{\frac{D_{o}^{t}\left(x^{t+1}, y^{t+1}\right)}{D_{o}^{t+1}\left(x^{t+1}, y^{t+1}\right)} \frac{D_{o}^{t}\left(x^{t}, y^{t}\right)}{D_{o}^{t+1}\left(x^{t}, y^{t}\right)}}$

To calculate the MPI for the sugar-producing state $k^{\prime}$ between $t$ and $t+1$ for a constant returnsto-scale (CRS) technology, the four different distance functions that make up the index, that is, $D_{o}^{t}\left(x^{k^{\prime}, t}, y^{k^{\prime}, t}\right), D_{o}^{t+1}\left(x^{k^{\prime}, t+1}, y^{k^{\prime}, t+1}\right), D_{o}^{t}\left(x^{k^{\prime}, t+1}, y^{k^{\prime}, t+1}\right)$, and $D_{o}^{t+1}\left(x^{k^{\prime}, t}, y^{k^{\prime}, t}\right)$, are to be calculated using a linear programming approach. For calculating outputoriented distance functions for the manufacturing sector of state $k^{\prime}$, the four different linear programming problems can be stated as: 
$D_{o}^{t+j}\left(x^{k^{\prime}, t+j}, y^{k^{\prime}, t+j}\right)^{-1}=\max \theta^{k^{\prime}}$

subject to

$\theta^{\mathrm{k}^{\prime}} y_{m}^{k^{\prime}, t+j} \leq \sum_{k=1}^{K} z^{k, t+i} y_{m}^{k, t+i}$,

$\sum_{k=1}^{K} z^{k, t+i} x_{n}^{k, t+i} \leq x_{n}^{k^{\prime}, t+j}$,

$z^{k, t+i} \geq 0$

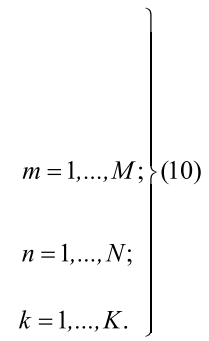

where $(i, j)=(0,0)$ for solving for $\left(D_{o}^{t}\left(x^{k^{\prime}, t}, y^{k^{\prime}, t}\right)^{-1}\right.$;

$(i, j)=(1,1)$ for solving for $\left(D_{o}^{t+1}\left(x^{k^{\prime}, t+1}, y^{k^{\prime}, t+1}\right)^{-1}\right.$;

$(i, j)=(0,1)$ for solving for $\left(D_{o}^{t}\left(x^{k^{\prime}, t+1}, y^{k^{\prime}, t+1}\right)^{-1}\right.$; and

$(i, j)=(1,0)$ for solving for $\left(D_{o}^{t+1}\left(x^{k^{\prime}, t}, y^{k^{\prime}, t}\right)^{-1}\right.$.

\section{Step 3: Bootstrapping Malmquist Productivity Index}

The data envelopment analysis (DEA) estimators include the random error in efficiency measures. Avkiran (2006) noted the following three types of errors discussed by Fethi and Jones (2006): i) measurement errors, which occur when the data used contain random errors of reporting and recording; ii) sampling errors, which arise when the data refer only to a subset of the possible populations of values that could have been recorded; and iii) specification errors, which occur when we are unsure of the underlying theoretical or population model that describes agents' behavior. Thus, distance functions are not free from random errors; techniques must be applied to split them from the point estimates. The basic idea of the bootstrap method proposed by Efron (1982) is to approximate the estimator's sampling distributions by using the empirical distribution of resampled estimates; this can be obtained from a Monte Carlo resampling simulation of the estimation procedure, where repeated resamples of the observed data produce repeated estimates. Using the Malmquist components and Malmquist routines in Frontier Efficiency Analysis with R (FEAR) software, the lower $\left(\hat{M}_{o i}^{*(\alpha)}\right)$ and upper $\left(\hat{M}_{o i}^{*(1-\alpha)}\right)$ confidence limits have been obtained for the observed value of MPI $\left(M_{o i}\right)$. If the original Malmquist index lies within the confidence interval, then the estimated Malmquist index is significantly different from unity (which would indicate productivity change) if any value of the interval does not include unity (Simar \& Wilson, 2000).

\section{Empirical Results}

This section reports the empirical results pertaining to sources of output growth and TFP growth in the Indian sugar industry. As noted above, the output growth can be broken down into two mutually exclusive components: i) input growth and ii) TFP growth. However, in practice, the input growth has been worked out as a residual obtained after deducting the TFP growth from output growth. We proceed with inter-temporal and inter-state variations in the output growth in the Indian sugar industry. In this context, Table 2 provides the relevant growth rates of sugar output. It has been observed that the sugar output in India has grown significantly at an average annual growth rate of 1.838 percent per annum during the entire study period. Nevertheless, the inter-state comparison highlights a substantial amount of variations in the growth rates of sugar output. The inter-state analysis shows that the sugar output in Orissa is growing with the highest average annual growth rate of 3.634 percent per annum. Additionally, in the states of Bihar, Gujarat, Karnataka and Uttar-Pradesh (UP), the sugar output has been observed to be rising at significant growth rates above 2 percent per annum. In contrast, a negative and insignificant growth of sugar output has been observed in the state of Rajasthan. Thus, excluding Rajasthan, a positive and statistically significant average annual growth rate of sugar output has been noticed for the remaining 11 states.

The comparative analysis of the growth rates of sugar output between pre- and post-reform periods reveal that over the two sub-periods, the output growth in the Indian sugar industry declined from 2.773 percent during the pre-reform period to 0.703 percent during the post-reform period. Thus, the reforms process seems to be adversely affecting the growth process in the Indian sugar industry. The inter-state analysis of the impact of economic reforms on sugar output reveals sluggishness in growth rates during the postreform period in all 12 sugar- producing states, except Bihar. The growth rate of the sugar output in Bihar has accelerated from 2.407 percent during the pre-reform period to 2.887 percent during the post-reform period. In addition, with the exception of Andhra Pradesh, Bihar, Gujarat and Uttar Pradesh, Indian states have exhibited negative rates in output growth during the post-reform period in contrast to positive output growth during the pre-reform period. 
Table 2. Yearly and Average annual Growth Rates of Output in the Indian Sugar Industry

\begin{tabular}{lccc}
\hline States & Entire Period & Pre-Reforms & Post-Reforms \\
\hline Andhra Pradesh & $1.936^{*}$ & $2.111^{*}$ & $1.724^{*}$ \\
Bihar & $2.623^{*}$ & $2.407^{*}$ & $2.887^{*}$ \\
Gujarat & $2.206^{*}$ & $3.193^{*}$ & $1.007^{*}$ \\
Haryana & $1.776^{*}$ & $3.512^{*}$ & $-0.331^{*}$ \\
Karnataka & $2.021^{*}$ & $2.334^{*}$ & -0.694 \\
Madhya Pradesh & $1.127^{*}$ & $2.620^{*}$ & $-0.686^{*}$ \\
Maharashtra & $1.169^{*}$ & $2.657^{*}$ & $-0.638^{*}$ \\
Orissa & $3.634^{*}$ & $6.023^{*}$ & $-0.733^{*}$ \\
Punjab & $1.570^{*}$ & $3.269^{*}$ & $-0.494^{*}$ \\
Rajasthan & -0.002 & 0.397 & -0.886 \\
Tamil Nadu & $1.016^{*}$ & $3.406^{*}$ & $-0.573^{*}$ \\
Uttar Pradesh & $2.294^{*}$ & $2.729^{*}$ & $1.765^{*}$ \\
All India & $1.838^{*}$ & $2.773^{*}$ & $0.703^{*}$ \\
\hline
\end{tabular}

Notes: i) Average annual growth rates have been computed using Semi-log function for the entire period and Kinked exponential function for two sub-periods; and ii) * represents that the value is significant at a 5 percent level of significance.

In summary, a declining trend was observed in the growth rates of sugar output in the Indian sugar industry in general and in the sugar industry of Indian states in particular. The decline also became more serious during the post-reform period. The results, therefore, describe an urgent need to study the sources of such sluggishness in the growth performance of India's sugar industry and in its 12 major sugar-producing states. The exploration of these sources entails the decomposition of output growth into two mutually exclusive components, namely, i) the inspiration component (i.e., TFP growth) and ii) the perspiration component (i.e., input growth). Both components have their own importance in augmenting output growth in the Indian sugar industry, and failing on any front might restrict the sugar-producing states from achieving the maximum potential growth in output.

\section{Decomposition of Output Growth in the Inspiration Component}

As mentioned earlier, the observed output growth can be decomposed into two mutually exclusive and nonadditive components, the 'perspiration' component, corresponding to factor accumulation, and the inspiration' component, corresponding to TFP growth. Table 3 provides the inter-temporal and inter-state variations in the TFP growth obtained using the Malmquist productivity index (MPI). Using the MPI, TFP growth has been observed using the relationship $T F P G=(M P I-1) \times 100$ . The analysis of Table 2 shows that TFP in the Indian sugar industry is growing at an average growth rate of 2.43 percent per annum. Notably, the observed TFP growth is statistically significant, given that the MPI lies within the confidence interval and that the interval does not contain unity. A comparison of the TFP growth of 2.43 percent with the output growth of 1.83 percent reflects a negative contribution of the perspiration component, i.e., factor accumulation. Thus, the analysis reveals that factor accumulation has restricted the Indian sugar industry from achieving its potential output growth. The results reiterate our earlier findings that a lack of factor inputs is causing underutilization of capacity and restricting the sugar firms from attaining their potential output. The inter-temporal analysis of TFP growth reveals that the average TFP growth has increased from 1.36 percent per annum during the prereform period to 3.66 percent per annum during the post-reform period. Thus, the speed of acceleration in TFP growth has been found to be 2.3 percent during the post-reform period. It is worth mentioning here that the 
Table 3. Inter-state Variations in Total Factor Productivity of the Sugar Industry in India

\begin{tabular}{|c|c|c|c|c|c|c|c|c|c|}
\hline \multirow{3}{*}{ States } & \multirow{3}{*}{$\begin{array}{l}\text { Entire } \\
\text { Period }\end{array}$} & \multirow{3}{*}{$\begin{array}{c}\text { Pre- } \\
\text { Reforms }\end{array}$} & \multirow{3}{*}{$\begin{array}{c}\text { Post- } \\
\text { Reforms }\end{array}$} & \multicolumn{6}{|c|}{ Confidence Intervals $(a=0.05)$} \\
\hline & & & & \multicolumn{2}{|c|}{ Entire Period } & \multicolumn{2}{|c|}{ Pre-Reforms } & \multicolumn{2}{|c|}{ Post-Reforms } \\
\hline & & & & Lower & Upper & Lower & Upper & Lower & Upper \\
\hline Andhra Pradesh & $1.0322^{*}$ & $1.0203^{*}$ & $1.0459^{*}$ & 0.9854 & 1.0674 & 1.0023 & 1.0473 & 0.9664 & 1.0908 \\
\hline Bihar & $1.0477^{*}$ & $1.0504^{*}$ & $1.0446^{*}$ & 0.9958 & 1.0724 & 1.0351 & 1.0649 & 0.9528 & 1.0810 \\
\hline Gujarat & $0.9938^{*}$ & $0.9569^{*}$ & $1.0376^{*}$ & 0.9245 & 1.0458 & 0.8986 & 1.0162 & 0.9549 & 1.0806 \\
\hline Haryana & $0.9852^{*}$ & $0.9685^{*}$ & $1.0047^{*}$ & 0.9156 & 1.0395 & 0.9124 & 1.0332 & 0.9193 & 1.0468 \\
\hline Karnataka & $1.0196^{*}$ & $0.9960^{*}$ & $1.0472^{*}$ & 0.9603 & 1.0679 & 0.9420 & 1.0480 & 0.9817 & 1.0911 \\
\hline Madhya Pradesh & $1.0496^{*}$ & $1.0457^{*}$ & $1.0541^{*}$ & 0.9981 & 1.0834 & 1.0253 & 1.0589 & 0.9678 & 1.1121 \\
\hline Maharashtra & $1.0487^{*}$ & $1.0467^{*}$ & $1.0509^{*}$ & 0.9975 & 1.0839 & 0.9988 & 1.0833 & 0.9960 & 1.0846 \\
\hline Orissa & $1.0308^{*}$ & $1.0390^{*}$ & $1.0215^{*}$ & 0.9631 & 1.0632 & 1.0132 & 1.0678 & 0.9089 & 1.0580 \\
\hline Punjab & $1.0306^{*}$ & $1.0190^{*}$ & $1.0439^{*}$ & 0.9773 & 1.0580 & 0.9786 & 1.0379 & 0.9758 & 1.0815 \\
\hline Rajasthan & $0.9964^{*}$ & $0.9838^{*}$ & $1.0110^{*}$ & 0.9410 & 1.0240 & 0.9489 & 1.0034 & 0.9322 & 1.0482 \\
\hline Tamil Nadu & $1.0179^{*}$ & $0.9951^{*}$ & $1.0447^{*}$ & 0.9614 & 1.0685 & 0.9583 & 1.0503 & 0.9649 & 1.0898 \\
\hline Uttar Pradesh & $1.0418^{*}$ & $1.0479 *$ & $1.0348^{*}$ & 1.0022 & 1.0734 & 1.0235 & 1.0812 & 0.9784 & 1.0646 \\
\hline All India\# & $1.0243^{*}$ & $1.0136^{*}$ & $1.0366^{*}$ & 0.9681 & 1.0621 & 0.9771 & 1.0491 & 0.9579 & 1.0773 \\
\hline
\end{tabular}

Notes: i) \# represent the geometric mean of 12 sugar-producing states; and ii) * represents that the value is significant at a level of significance $a=0.05$.

increase in TFP growth has been obtained by subtracting 1.36 percent TFPG, from during the pre-reform period, from 3.66 percent TFPG, from during the post-reform years. Bootstrapping the Malmquist index reveals that during both sub-periods, TFP growth is statistically significant at the 5 percent level of significance. The statistical significance of TFP growth ensures that the inspiration component (i.e., TFP growth) is contributing significantly to output growth in the Indian sugar industry. Hence, the observed output growth in the Indian sugar industry is robust and sustainable in the long run.

The inter-temporal analysis of TFP growth also reveals that the industry achieved the highest rate of TFP growth above 8 percent in the years 1995/96 and 1996/97. Notably, during the period1995/96, a record production of 164 lakh tonnes was achieved, which created a surplus stock of 55 lakh tonnes after meeting the domestic requirements. The government absorbed only 5 lakh tonnes of sugar to maintain the buffer stocks, and 5 lakh tonnes of sugar were permitted to be exported. The industry demanded the following from the government: i) that it create an additional buffer stock of 20 lakh tonnes; ii) that it decontrol the industry on a long-term basis; and iii) that it allow for exports of sugar on a regular basis for absorbing the excess supply, if any. Additionally, the industry raised the issue of imposing customs and auxiliary duties on imports of sugar. However, the government paid no attention to the industry's demands, which discouraged sugar production in coming years. For example, in the period 1996/97, the level of sugar production fell to 129 lakh tonnes from 164 lakh tonnes in the period 1995/96. This decline occurred because of sugar crushing delays resulting from the dispute between the government and the Indian sugar mills association. Non-payments of sugarcane arrears in this year discouraged the sowing of sugarcane, which reduced the supply of sugarcane for crushing for the next year. This restricted the sugar firms from utilizing their optimum capacity. On the whole, tight regulatory policies discouraged sugar firms from attaining their potential growth in sugar output in the succeeding years (i.e., 1997/98 onwards). Consequently, the TFP growth fell and was observed to hover around 2 to 3 percent during the succeeding eight years of the study period (i.e., $1997 / 98$ to $2004 / 05$ ). 
An inter-state analysis of TFP growth reveals that during the entire study period, the average TFP growth ranged between the minimum of (-)1.48 percent for the state of Haryana and the maximum of 4.96 percent for the sugar industry of Madhya Pradesh. The six states of Bihar, Madhya Pradesh, Maharashtra, Orissa, Punjab, and Uttar-Pradesh had growth rates above the all-India average TFP growth. Even among these states, the TFP in the sugar industry of Bihar, Madhya Pradesh, Maharashtra and Uttar Pradesh were found to be growing above 4 percent per annum. Two states, Gujarat and Haryana, have recorded a TFP regress, with negative TFP growth rates of (-)0.62 percent and (-)1.48 percent per annum, respectively.

While analyzing the impact of economic reforms on TFP growth in the sugar industry of the 12 major sugarproducing states, we note that the rate of TFP growth fell in the three states of Bihar, Orissa and Uttar Pradesh during the post-reform period relative to the pre-reform period. The remaining nine states, however, experienced acceleration in the rates of TFP growth during the post-reform period. Even the states of Gujarat and Haryana, which experienced negative TFP growth during the entire study period, were found to be growing with positive rates of 3.76 and 0.47 percent, respectively, during the post-reform period. Further, TFP growth in the states of Madhya Pradesh and Maharashtra grew at rates above 5 percent per annum during the post-reform years. The higher TFP growth in Maharashtra relative to that of Uttar Pradesh during the post-reform period might be the most potent reason for Maharashtra's performance in terms of sugar production and the number of sugar mills in recent years. The horizontal expansion of sugar firms in Maharashtra also might be due to high productivity of the state in the sugar production process. It is worth noting that based on confidence intervals obtained from bootstrapping MPI, the TFP growth rates in all of the 12 major sugar-producing states are statistically significant.

It is evident from the above analysis that the contribution of TFP growth in output growth relative to input growth is substantial in the Indian sugar industry at both aggregate and state levels. The higher TFP growth in the post-reform years seems to be a guarantee that output growth in the Indian sugar industry will be sustainable in the long run. Nevertheless, an analysis of the sources of TFP growth is needed to explain the changes in TFP. As noted in Section 2, the Malmquist productivity index (MPI) allows TFP growth to be decomposed into two mutually exclusive components: i) technical efficiency change (an index of catching up); and ii) technological change (an index of technological upgrades and advancement). What follows is the analysis of the sources of TFP growth in the Indian sugar industry.

\section{Efficiency Change in the Indian Sugar Industry}

The efficiency change index identifies changes in the input-output mix and represents the movement of a decision making unit (DMU) towards the best-practice frontier. In general, the efficiency change is an indicator of catching up and depicts the movement of a DMU towards the best-practice frontier using the learning-bydoing process. A value in the efficiency change index above unity reflects the movement of a sugar-producing state under evaluation towards the best-practice production frontier and vice versa. Table 4 provides the technical efficiency change (ECH) index for the sugar-producing states of India. We note that during the entire study period, the efficiency in the production operations has improved at a rate of 2.86 percent per annum. Thus, the contribution of efficiency change to TFP growth (and consequently to output growth) is significantly positive. Higher growth rates of ECH (2.86 percent) than the rate of TFP growth ( 2.43 percent) indicate the presence of the phenomenon of technical regress in the Indian sugar industry during the entire study period. The sub-period analysis reveals that because of a substantial decline in the extent of technical efficiency during the post-reform years, the phenomenon of catching up that was more pronounced in the pre-reform period completely disappeared from the scene. This is evident from the fact that ECH declined at the rate of (-)2.10 percent per annum during the post-reform years, while it grew at the rate of 7.40 percent per annum during the pre-reform period. Contrary to this, we noted the presence of a strong phenomenon of innovation or frontier shift in the post-reform years, which prompted a reverse trend in the behavior of technological change in both sub-periods. Statistics showing the rate of technical progress at 5.88 percent per annum in the post-reform years, compared with the rate of technical regress (-)5.62 percent per annum during the pre-reform period, validate our above inference. 
Table 4. Inter-state Variations in Efficiency Change of the Sugar Industry in India

\begin{tabular}{|c|c|c|c|c|c|c|c|c|c|}
\hline \multirow{3}{*}{ States } & \multirow{3}{*}{$\begin{array}{l}\text { Entire } \\
\text { Period }\end{array}$} & \multirow{3}{*}{$\begin{array}{c}\text { Pre- } \\
\text { Reforms }\end{array}$} & \multirow{3}{*}{$\begin{array}{c}\text { Post- } \\
\text { Reforms }\end{array}$} & \multicolumn{6}{|c|}{ Confidence Intervals ( $a=0.05$ ) } \\
\hline & & & & \multicolumn{2}{|c|}{ Entire Period } & \multicolumn{2}{|c|}{ Pre-Reforms } & \multicolumn{2}{|c|}{ Post-Reforms } \\
\hline & & & & Lower & Upper & Lower & Upper & Lower & Upper \\
\hline Andhra Pradesh & $1.0302^{*}$ & $1.0854^{*}$ & $0.9704^{*}$ & 0.9202 & 1.1318 & 1.0193 & 1.1762 & 0.8187 & 1.0832 \\
\hline Bihar & $1.0556^{*}$ & $1.1208^{*}$ & $0.9857^{*}$ & 0.9092 & 1.1462 & 1.0493 & 1.1999 & 0.7719 & 1.0878 \\
\hline Gujarat & $0.9897^{*}$ & $0.9951^{*}$ & $0.9835^{*}$ & 0.8529 & 1.1217 & 0.8981 & 1.1439 & 0.8040 & 1.0969 \\
\hline Haryana & $1.0022^{*}$ & $1.0167^{*}$ & $0.9859^{*}$ & 0.8190 & 1.1754 & 0.8525 & 1.2181 & 0.7824 & 1.1285 \\
\hline Karnataka & $1.0184^{*}$ & $1.0516^{*}$ & $0.9818^{*}$ & 0.9097 & 1.1362 & 0.9790 & 1.1751 & 0.8364 & 1.0933 \\
\hline Madhya Pradesh & $1.0324^{*}$ & $1.0979^{*}$ & $0.9623^{*}$ & 0.8939 & 1.1326 & 1.0201 & 1.1662 & 0.7686 & 1.0953 \\
\hline Maharashtra & $1.0402^{*}$ & $1.0820^{*}$ & $0.9944^{*}$ & 0.9283 & 1.1604 & 0.9970 & 1.2174 & 0.8556 & 1.0985 \\
\hline Orissa & $1.0463^{*}$ & $1.1120^{*}$ & $0.9759^{*}$ & 0.9551 & 1.1469 & 1.0334 & 1.2102 & 0.8728 & 1.0785 \\
\hline Punjab & $1.0410^{*}$ & $1.0902^{*}$ & $0.9875^{*}$ & 0.9186 & 1.1468 & 1.0093 & 1.2005 & 0.8249 & 1.0884 \\
\hline Rajasthan & $1.0119^{*}$ & $1.0620^{*}$ & $0.9576^{*}$ & 0.8820 & 1.1093 & 0.9898 & 1.1560 & 0.7731 & 1.0583 \\
\hline Tamil Nadu & $1.0184^{*}$ & $1.0541^{*}$ & $0.9792^{*}$ & 0.8961 & 1.1370 & 0.9922 & 1.1694 & 0.7975 & 1.1012 \\
\hline Uttar Pradesh & $1.0592 *$ & $1.1289^{*}$ & $0.9847^{*}$ & 0.9540 & 1.1660 & 1.0568 & 1.2475 & 0.8487 & 1.0795 \\
\hline All India\# & $1.0286^{*}$ & $1.0740^{*}$ & $0.9790^{*}$ & 0.9025 & 1.1424 & 0.9896 & 1.1897 & 0.8122 & 1.0907 \\
\hline
\end{tabular}

Notes: i) \# represent the geometric mean of 12 sugar-producing states; and ii) * represents that the value is significant at a 5 percent level of significance.

An inter-state analysis of technical efficiency change for the entire study period reveals that, with the exception of Gujarat, technical efficiency grew in all states. The highest efficiency improvements were observed in the sugar industry of Uttar Pradesh (5.92 percent) and Bihar (5.56 percent). Further, ECH at a rate of greater than 4 percent was observed in the sugar industries of Maharashtra, Orissa, and Punjab. The comparative analysis of ECH between distinct sub-periods reveals that a decline in efficiency was pervasive during the post-reform period; all sugar-producing states experienced negative growth rates in technical efficiency during the post-reform years. This implies that the reform process has affected the operating efficiency of sugar firms adversely.

\section{Technical Progress in Indian Sugar Industry}

As noted above, another component of the Malmquist TFP index is technological change (TECH). TECH is used as a proxy for innovation in the production process. Table 5 provides the inter-temporal and inter-state variations in technical change in the Indian sugar industry. We note that there exists a technological regress in the Indian sugar industry during the en- tire study period, and the rate of this regress is (-)0.42 percent per annum. Given this regress, we can say that TFP growth in the Indian sugar industry is entirely composed of technical efficiency changes, and more specifically, by pure technical efficiency changes. The behavior of technological change between distinct subperiods depicts a significant reverse trend as supported by the fact that technical progress occurred at a significant rate of 5.88 percent per annum in the post-reform period in contrast to a technical regress at the rate of (-)5.62 percent per annum in the pre-reform period. However, the impact of technological regress in the pre-reform period outweighs that of technical progress in the post-reform period; this resulted in a significant regress for the entire study period (see Table 4). Simply, the observed technical regress in the Indian sugar industry occurred as a result of the enormous technical regress during the pre-reform period. Notably, the negative technical progress during the pre-reform period might be the consequence of the stiff regulatory environment imposed upon the industry during this period. Under adverse environmental conditions, firms face trouble in adopting new technology. This situation is worse for the efficient firms because they 
Table 5.Inter-state Variations in Technological Change of the Sugar Industry in India

\begin{tabular}{|c|c|c|c|c|c|c|c|c|c|}
\hline \multirow{3}{*}{ States } & \multirow{3}{*}{$\begin{array}{l}\text { Entire } \\
\text { Period }\end{array}$} & \multirow{3}{*}{$\begin{array}{c}\text { Pre- } \\
\text { Reforms }\end{array}$} & \multirow{3}{*}{$\begin{array}{c}\text { Post- } \\
\text { Reforms }\end{array}$} & \multicolumn{6}{|c|}{ Confidence Intervals ( $a=0.05$ ) } \\
\hline & & & & \multicolumn{2}{|c|}{ Entire Period } & \multicolumn{2}{|c|}{ Pre-Reforms } & \multicolumn{2}{|c|}{ Post-Reforms } \\
\hline & & & & Lower & Upper & Lower & Upper & Lower & Upper \\
\hline Andhra Pradesh & $1.0020^{*}$ & $0.9400^{*}$ & $1.0778^{*}$ & 0.8852 & 1.0829 & 0.8543 & 0.9906 & 0.9219 & 1.1990 \\
\hline Bihar & $0.9925^{*}$ & $0.9372^{*}$ & $1.0597^{*}$ & 0.8741 & 1.0734 & 0.8618 & 0.9899 & 0.8884 & 1.1774 \\
\hline Gujarat & $1.0042^{*}$ & $0.9617^{*}$ & $1.0550^{*}$ & 0.8529 & 1.0883 & 0.8050 & 1.0233 & 0.9111 & 1.1677 \\
\hline Haryana & $0.9831^{*}$ & $0.9526^{*}$ & $1.0191^{*}$ & 0.7634 & 1.1105 & 0.7245 & 1.0702 & 0.8103 & 1.1583 \\
\hline Karnataka & $1.0011^{*}$ & $0.9472^{*}$ & $1.0666^{*}$ & 0.8736 & 1.0763 & 0.8294 & 0.9938 & 0.9270 & 1.1789 \\
\hline Madhya Pradesh & $1.0167^{*}$ & $0.9525^{*}$ & $1.0954^{*}$ & 0.8963 & 1.1108 & 0.8840 & 1.0079 & 0.9106 & 1.2414 \\
\hline Maharashtra & $1.0081^{*}$ & $0.9674^{*}$ & $1.0568^{*}$ & 0.8708 & 1.0837 & 0.8247 & 1.0206 & 0.9266 & 1.1607 \\
\hline Orissa & $0.9852^{*}$ & $0.9344^{*}$ & $1.0467^{*}$ & 0.8626 & 1.0653 & 0.8452 & 0.9882 & 0.8829 & 1.1609 \\
\hline Punjab & $0.9900^{*}$ & $0.9347^{*}$ & $1.0572^{*}$ & 0.8677 & 1.0652 & 0.8194 & 0.9872 & 0.9264 & 1.1618 \\
\hline Rajasthan & $0.9847^{*}$ & $0.9264^{*}$ & $1.0558^{*}$ & 0.8695 & 1.0638 & 0.8296 & 0.9755 & 0.9175 & 1.1747 \\
\hline Tamil Nadu & $0.9995^{*}$ & $0.9440^{*}$ & $1.0669^{*}$ & 0.8732 & 1.0819 & 0.8461 & 0.9923 & 0.9053 & 1.1942 \\
\hline Uttar Pradesh & $0.9835^{*}$ & $0.9282^{*}$ & $1.0508^{*}$ & 0.8709 & 1.0564 & 0.8218 & 0.9805 & 0.9307 & 1.1503 \\
\hline All India\# & $0.9958^{*}$ & $0.9438^{*}$ & $1.0588^{*}$ & 0.8627 & 1.0797 & 0.8279 & 1.0014 & 0.9043 & 1.1769 \\
\hline
\end{tabular}

Notes: i) \# represent the geometric mean of 12 sugar-producing states; and ii) * represents that the value is significant at a 5 percent level of significance.

might face problems in using the same input-output mix to which they were previously accustomed and, thus, cannot produce with the optimum input-output mix and resource utilization. The observed level of best-practice technology also might deteriorate, as reflected by a downward shift in the industry's production frontier. This technical regress is a different phenomenon than a decrease in efficiency because it also affects the most efficient firms. Indeed, the measured efficiency level of the inefficient firms might improve during the period of adversity as a result of the 'regress' of the most efficient firms; for example, the frontier might move closer to the inefficient firms rather than the inefficient firms moving closer to the frontier (Farrantino and Ferrier, 1996).

Table 5 further reveals that the sugar industries of five states (Andhra Pradesh, Gujarat, Karnataka, Madhya Pradesh, and Maharashtra) have experienced technical progress during the entire study period. We also noticed a technical regress in the remaining seven sugar-producing states. The comparison of technical change during two sub-periods also supports the infer- ence of an improvement in technical change during the post-reform period. During the post-reform period, each sugar-producing state has recorded acceleration in the speed of technical change. Except for the states of Haryana and Orissa, the rate of technical progress in the sugar-producing states is above 5 percent per annum. Such acceleration in the speed of technical progress during the post-reform period is the consequence of the deregulatory environment followed by India's policy planners. Although deregulation in the Indian sugar industry started from the year 1998, the liberalized macroeconomic policy of the Indian government resulted in a significant improvement in the speed of technical progress.

\section{Decomposition of Output Growth in the Perspiration Component}

The second component of output growth, as explained by Solow (1957), is the perspiration component, which represents the factor accumulation or input growth over the given period of time. With the assumption of no input change (i.e., with same bundle of inputs dur- 
Table 6. Growth Rates of Perspiration Component in the Sugar Industry of India

\begin{tabular}{lccc}
\hline States & Entire Period & Pre-Reforms & Post-Reforms \\
\hline Andhra Pradesh & -1.284 & 0.077 & -2.868 \\
Bihar & -2.146 & -2.633 & -1.574 \\
Gujarat & 2.827 & 7.499 & -2.757 \\
Haryana & 3.252 & 6.657 & -0.798 \\
Karnataka & 0.062 & 2.733 & -5.417 \\
Madhya Pradesh & -3.836 & -1.951 & -6.098 \\
Maharashtra & -3.696 & -2.015 & -5.725 \\
Orissa & 0.555 & 2.121 & -2.88 \\
Punjab & -1.488 & 1.366 & -4.888 \\
Rajasthan & 0.356 & 2.014 & -1.986 \\
Tamil Nadu & -0.777 & 3.9 & -5.044 \\
Uttar Pradesh & -1.882 & -2.059 & -1.715 \\
All India & -0.592 & 1.411 & -2.96 \\
\hline
\end{tabular}

Note: The formula has been used to obtain the growth rates of the perspiration component under the Growth Accounting Framework.

ing each year), the industry could achieve the output growth rate equal to the growth of TFP, but if input growth is positive, we may expect a higher growth of output. Table 6 provides inter-temporal and interstate variations in the growth contribution of inputs in the Indian sugar industry. A negative value explains a negative contribution, and a positive value represents a positive contribution of factor accumulation to output growth. The analysis presented inTable 6 shows that the average growth of the inputs during the entire study period is -0.592 percent per annum. Thus, negative input growth during the entire study period reflects a negative contribution of input growth to a rate of -0.592 percent per annum. Therefore, input growth drags down output growth in the Indian sugar industry because its contribution is negative.

A comparison of input growth rates between two subperiods reveals that during the pre-reform period, input growth contributed positively; this contribution is equal to 1.411 percentage points of 2.773 percent of output growth (see Table 1 for the growth rates of output). Thus, approximately 51 percent of the output growth in the Indian sugar industry during the pre-reform period can be explained by input growth, with the remaining attributed to TFP growth. However, during the post-reform period, a deceleration in input growth was observed. The growth of inputs during the post-reform period was observed to be a rate of -2.96 percent per annum. Despite this negative growth, the output could grow at a rate of 0.703 percent per annum given a significant TFP growth of 3.66 percent per annum during the post-reform period. Thus, the negative growth of inputs restricts the sugar industry of India from exploiting the gains of TFP growth to achieve the sustained output growth.

In summary, the decomposition of output growth in the Indian sugar industry supports the inference that output growth in the Indian sugar industry is equally driven by both the inspiration component (i.e., TFP growth) and the perspiration component (i.e., factor accumulations), though in opposite directions. Given substantial TFP growth, the potential output growth in the Indian sugar industry has been restricted primarily by the negative growth of inputs (because of insufficient supply of sugarcane) during the entire study period and the post-reform period.

An inter-state analysis also highlights negative growth and contribution of inputs during the post-reform period in comparison to the pre-reform period. In the states of Bihar, Madhya Pradesh, Maharashtra, and Uttar Pradesh, the contribution of input growth 
was negative even during the pre-reform period and remained negative during the post-reform period. However, in the remaining states, input contributions became negative during the post-reform period, in contrast to a positive contribution in the pre-reform period. Thus, the negative growth of inputs is a countrywide phenomenon and not limited to a particular state. This evidence supports the conclusions drawn from the earlier chapter, noting that the sugar-producing states underutilize the available capacity because of a slackening in inputs. Therefore, substantial growth in inputs is required to achieve sustained growth in the Indian sugar industry and any policy seeking to boost the growth of inputs in the sugar industry must aim to augment the growth of sugarcane at farm level.

\section{Conclusions and Relevant Policy Implications}

The decomposition of output growth in the Indian sugar industry reveals that the inspiration component of output growth (i.e., TFP growth) has a significant contribution; TFP has been growing at an average rate of 2.43 percent per annum. However, negative growth in the perspiration component at a rate of -0.592 percent per annum has restricted the Indian sugar industry from achieving potential output growth rates. Further, inter-state analysis reveals that the output growth in the sugar industry of Orissa is growing, with the highest average annual growth rate of 3.634 percent. Moreover, barring the state of Rajasthan, the remaining 11 states were found to be growing with positive and statistically significant rates of sugar output. Analysis of the impact of economic reforms on the sugar industry's growth reveals that all 12 sugar-producing states except Bihar recorded lesser output growth rates during the post-reform period relative to the pre-reform period. Except for the states of Andhra Pradesh, Bihar, Gujarat, and Uttar Pradesh, a declining trend in output was observed during the post-reform period, in contrast to a rising trend in the pre-reform period. The growth accounting framework shows that TFP growth is the dominating source of output growth, which is primarily attributable to overall efficiency change during the entire and pre-reform study periods. However, the second component of productivity growth (i.e., technical progress) is a relatively scant source of TFP and output growth during these two periods. More- over, a decline in the growth rate of technical efficiency was observed to be the major cause of sluggishness in TFP growth during the post-reform period. The deceleration in technical efficiency is the consequence of an acceleration in the rate of technical progress despite the economic liberalization and reform process initiated by the Indian government. The fragile catchingup of the sugar-producing states to the newly shifted best-practice frontiers seems to be adversely affecting the rate of growth of technical efficiency.

However, the perspiration component of output growth (i.e., inputs growth) recorded a negative value, indicating its negative contribution to output growth. Further, during the pre-reform period, the growth of inputs was positive and contributed 1.411 percentage points of 2.773 percent of output growth. However, during the post-reform period, a deceleration in input growth was observed, and the contribution of input growth was negative. Despite this negative contribution of input growth, the output growth could increase by 0.703 percent per annum because of a significant TFP growth of 3.66 percent during the post-reform period. The policy implication of this fact is that the negative growth of input restricts the sugar industry of India from exploiting the gains of total factor productivity growth to achieve the sustained output growth.

An inter-state analysis also reveals a negative contribution of inputs during the post-reform period in comparison with the pre-reform period. In Bihar, Madhya Pradesh, Maharashtra and Uttar Pradesh, the contribution of input growth is found to be negative throughout the study period. However, in the remaining states, the input contribution became negative during the post-reform period, in contrast to a positive contribution during the pre-reform period. Thus, the negative growth of inputs restricts the sugar industry of Indian states from achieving maximum potential growth rates of output. The evidence thus supports the findings of Kumar and Arora (2010) that reflect the underutilization of capacity due to input slackening. Therefore, a substantial growth of inputs, especially of sugarcane, is required to achieve sustained growth in the Indian sugar industry. Efforts must be undertaken to improve per hectare productivity and quality in terms of sucrose contents of sugarcane. Any policy in this regard must be welcomed for augmenting the input growth in the industry. 
In summary, the analysis supports the inference that inadequate factor accumulation and lack of affective catching-up (i.e., growth of technical efficiency) restrict the sugar industry from attaining maximum potential output growth. Although technical progress (element of inspiration component) contributes to output growth significantly, the fragile catching-up and slow input growth have proven to be a restraint for potential growth in the Indian sugar industry. To converge the inter-state technical efficiency differentials, industry experts must utilize an effective policy framework. Thus, "catching up" the technological, managerial and knowledge differences as soon as possible is necessary from the technical efficiency perspective. However, to improve input growth, effective planting of sugarcane is required in the Indian subcontinent. Although sugarcane production may reap substantial profits for farmers, they are reluctant to grow sugarcane because of delays in the payments of arrears by the sugar firms. The sickness of sugar firms always leads to a delay in the payment of sugarcane arrears to the farmers. Both the sickness and payment delays are caused by intense political interference, from the purchase of raw material to the sale of sugar. The dominance of a number of cooperative joint-sector sugar firms and public-sector sugar firms reflects the rigorous interference of public sectors in the sugar production process. This interference is subject to bureaucratic control and always restricts managers from optimizing the time constraints and choosing the optimum product mix. Thus, a delay in decision making forces management to make selections that seldom ensure technically efficient allocation of resources. Thus, the deregulation policy, coupled with effective catching-up and better inputs growth, may produce sizeable growth in the sugar industry in general and in sugar-producing states in particular.

\section{References}

Ahluwalia, I. J. (1991). Productivity Growth in Indian Manufacturing. New Delhi: Oxford University Press. Avkiran, N. K. (Ed.). (2006). Productivity Analysis in the Services Sector with Data Envelopment Analysis ( $3^{\text {rd }}$ ed.). Camira: The University of Queensland.

Beri, C. C. (1962), Measurements of Production and Productivity in Indian Industry. New Delhi: Asia Publishing House.
Caves, D. W., Christensen, L. R., \& Diewert, E. W. (1982). The Economic Theory of Index Numbers and the Measurement of Input, Output and Productivity. Econometrica, 50(6), 1393-1414.

Chattopadhyay, S. K. (2004). Trends in Total Factor Productivity of Manufacturing Sector in West Bengal: A Sectoral and Temporal Analysis (Occasional Paper No. 25(1,2,3)). Reserve Bank of India. Retrieved from: http://rbidocs.rbi.org.in/rdocs/ publications/pdfs/66985.pdf

Dawar, K. R. (1990). Returns to Scale and Factor Productivity in the Cooperative Sugar Industry in Punjab and Haryana. Indian Journal of Industrial Relations, 26(2), 166-174.

Efron, B. (1982). The Jacknife, the Bootstrap and Other Resampling Plan. CBMS-NSF Regional Conference Series in Applied Mathematics. No. 38. Philadelphia, PA: Society for Industrial and Applied Mathematics.

Färe, R., Grosskopf, S., \& Lovell, C. A. K. (1994), Production Frontiers. Cambridge, UK: Cambridge University Press.

Ferrantino, M. J., \& Ferrier, G. D. (1996). Best-Practice Technology in an Adverse Environment: The Case of Indian Sugar, 1981-1986. Journal of Economic Behaviour and Organization, 29(3), 493-522.

Fethi, M. D., \& Jones, T. G. W. (2006). Stochastic Data Envelopment Analysis. In N.K. Avkiran (Ed.), Productivity Analysis in the Services Sector with Data Envelopment Analysis. (3rd ed.) (chapter 16). Australia: University of Queensland Business School, The University of Queensland.

Goldar, B., \& Kumari, A. (2003). Import Liberalization and Productivity Growth in Indian Manufacturing Industries in the 1990s. The Developing Economies, 41(4), 436-460.

Gupta, G. S., \& Patel, K. (1976). Production Function in Indian Sugar Industry. Indian Journal of Industrial Relations, 11(3), 315-337.

Kumar, S. (2001). Productivity and Factor Substitution: Theory and Analysis. New Delhi: Deep and Deep Publications Pvt. Ltd.

Kumar, S. (2003). Inter-Temporal and Inter-State Comparison of Total Factor Productivity in Indian Manufacturing Sector: an Integrated Growth Accounting Approach. ArthaVijnana, 45(3-4), $161-184$ 
Kumar, S. (2006). A Decomposition of Total Productivity Growth: A Regional Analysis of Indian Industrial Manufacturing Growth. International Journal of Productivity and Performance Measurement, 55(3-4), 311-331.

Kumar, S., \& Arora, N. (2009). Does Inspiration or Perspiration Drive Output Growth in Manufacturing Sector? An Experience of Indian States. The Indian Journal of Economics, 89(355), 569-598.

Kumar, S., \& Arora, N. (2010). Analyzing Regional Variations in Capacity Utilization of Indian Sugar Industry using Non-parametric Frontier Technique. Eurasian Journal of Business \& Economics, 2(4), 1-26.

Mehta, S. S. (1974). Analysis of Sugar Industry-A Production Function Approach. Anvesak, 4(2), 197-205.

Mitra, A. (1999). Total Factor Productivity Growth and Technical Efficiency in Indian Industries. Economic \& Political Weekly, 34(31), 98-105.

Neogi, C., \& Ghosh, B. (1998). Impact of Liberalization on performance of Indian Industries: A firm level study. Economic and Political Weekly, 33(9), 16-24.

Pandey, A. P. (2007). Indian Sugar Industry-A Strong Industrial Base for Rural India (MPRA Paper No. 6065). Retrieved from http://mpra.ub.unimuenchen.de/6065/

Pradhan, G., \& Barik, K. (1999). Total Factor Productivity Growth in Developing Economies: a study of selected industries in India. Economic and Political Weekly, 34(31), 92-97.

Ray, S. C. (1997). Regional Variation in Productivity Growth in Indian Manufacturing: A Nonparametric Analysis. Journal of Quantitative Economics, 13(1), 73-94.

Ray, S. (2002). Economic Reforms and Efficiency of Firms: The Indian Manufacturing Sector During the Nineties. New Delhi. India: Institute of Economic Growth. Retrieved August 2, 2011, from: http://depot.gdnet.org/gdnshare/pdf2/gdn_library/awards_medals/2003/r_m/reform_institutions/ray_paper.pdf

Sanyal, N., Bhagria, R. P., \& Ray, S. C. (2008). Indian Sugar Industry. YOJANA. 52(4), 13-17.

Sastry, V. S. R. K. (1966). Measurement of Productivity and Production Functions in Sugar Industry in India: 1951-1961. Indian Journal of Industrial Relations, 2(1), 70-94.
Sharma, S., \& Upadhyay, V. (2003-04). An Analysis of Total Factor Productivity in Indian Fertilizer Industry. Indian Economic Journal, 51(1), 89-105.

Shephard, R. W. (1979), Theory of cost and production functions. New Jersey, NJ.: Princeton Studies in Mathematical Economics No 4.

Simar, L., \& Wilson, P. W. (2000). A General Methodology for Bootstrapping Nonparametric Frontier Models. Journal of Applied Statistics, 27(6), 779-802.

Singh, P. N. (1964). A Study off Productivity in Export Industry: Sugar in U.P. Indian Journal of Labour Economics, 6(4), 353-359.

Singh, M. P., \& Singh, N. (1984). Sharing of Productivity Gains in Indian Sugar Industry: An Empirical Study. Indian Journal of Industrial Relations, 20(2), 222-230.

Singh, T. (2000-01). Total Factor Productivity in the Manufacturing industries in India. The Indian Economic Journal, 48(2), 108-117.

Singh, S. P., \& Agarwal, S. (2006). Total Factor Productivity Growth, Technical Progress and Efficiency Change in Sugar Industry of Uttar Pradesh. The Indian Economic Journal, 54(2), 59-82.

Solow, R. M. (1957). Technical Change and Aggregate Production Function. Review of Economics and Statistics. 39(3), 312-320.

Thomas, K. V. (2010). The response of the minister of state for food and agriculture in response to a written query in the Lok Sabha. published on Nov. 23, 2010. Information accessed on August 2, 2011. Electronically Retrieved from http://www. business-standard.com/india/news/162-sugarmills-in-indiasick-thomas/116929/on

\section{Acknowledgements}

We would like to thank the anonymous reviewers and the editor of Journal for providing useful comments and suggestions that have resulted in significant improvements in the quality of the paper. Errors remain unerringly our own. 